\title{
MIR15A wt Allele
}

National Cancer Institute

\section{Source}

National Cancer Institute. MIR15A wt Allele. NCI Thesaurus. Code C81885.

The human MIR15A wild-type allele is located in the vicinity of $13 q 14.3$ and is approximately $82 \mathrm{~b}$ in length. This allele, which encodes MIR15A pre-miRNA, plays a role in the regulation of gene expression. Alteration in the expression of this gene is associated with carcinoma of the prostate, polycystic kidney disease, polycystic liver disease, pituitary adenoma, acute promyelocytic leukemia, chronic lymphocytic leukemia and chronic myelogenous leukemia. 